\title{
ПРАВОВАЯ ПРИРОДА ИНФОРМАЦИОННЫХ ПРАВ
}

\author{
(C) 2020 Ревина С. Н. \\ доктор юридических наук, профессор кафедры публичного права \\ Самарский государственный экономический университет, Россия, Самара \\ E-mail: 29.revina@mail.ru \\ (C) 2020 Казарян А.Г. \\ аспирант 3 курса \\ Самарский государственный экономический университет, Россия, Самара \\ E-mail: hak-kazaryan@mail.ru
}

Процесс развития современного государства характеризуется введением новейших информационных технологий, значительным ускорением процесса получения, обработки, анализа информации. Правоотношения в сфере доступа к публичной информации непосредственно связаны с реализацией конституционных положений относительно соблюдения и надлежащей реализации прав и свобод человека и гражданина. Обеспечения информационных прав связано с общими проблемами реформирования государственного аппарата и важности адаптации информационного законодательства для создания современных форм государственного администрирования информационных отношений.

Обеспечение информационных прав, в том числе и с помощью административно-правовых средств, является одной из тем, которая часто становится предметом особого внимания отечественных ученых-юристов. В исследованиях этих ученых освещались вопросы, связанные, в частности, с определением административно-правового статуса лица, механизмом обеспечения прав и свобод человека и гражданина, деятельностью органов государственной власти в этой сфере.

В то же время специальные научные исследования по публично-правовому обеспечению информационных прав подтверждают необходимость глубокого исследования механизма административно-правового обеспечения органами государственной власти права на свободный доступ к публичной информации и свидетельствуют об актуальности выбранной темы.

Ключевые слова: информационные права, право на информацию, правовое регулирование, публичноправовое обеспечение, субъективные права, информационное общество, информационные технологии, информационные отношения, информационно-инфраструктурные отношения, общественные отношения.

Правовая природа информационной сферы, информационной инфраструктуры, реализации общественных отношений, связанных с информацией, позволяет сделать предположение о том, что в информационной сфере существуют две особые группы общественных отношений, регулируемых нормами информационного права. К первой группе, несомненно, относятся те отношения, которые уже получили название информационных отношений, то есть отношений, связанных с оборотом информации - ее созданием, распространением, использованием, хранением и уничтожением. А вторую группу образуют общественные отношения, в которых участвуют элементы информационной инфраструктуры и правовое регулирование которых имеет особенности именно благодаря тому, что они участвуют в обеспечении оборота информации [1]. Предва- рительно назовем эти общественные отношения - информационно-инфраструктурными отношениями.

Проблема правоотношений относится к наиболее важным и дискуссионным как в общей теории права [2], так и в теории отдельных отраслей права.

На наш взгляд наиболее рациональная классификация информационных прав была сделана С.Ф. Кечекьяном еще в 1958 году, который выделяет следующие группы вопросов в проблематике правоотношений: содержание правоотношений и их взаимосвязь с нормами права, субъективное право и правовая обязанность в правоотношениях, субъекты права в правоотношениях, объект права в правоотношениях и условия возникновения, изменения и прекращения правоотношений [3]. 
Но все же следует согласиться с Е.З.Бекбаевым в том, что в настоящее время в юридической науке все ученые признают наличие так называемых конкретных или реальных правоотношений между определенными субъектами правовой сферы, которые в силу наступления определенных юридических фактов являются обладателями корреспондирующих друг к другу субъективных прав и юридических обязанностей [4].

Современные авторы, к сожалению, не придают должного значения описания взаимосвязи правоотношений собственно с правом. Так М.И.Абдулаев [5] никоим образом не охарактеризовал природу субъективных прав и обязанностей сторон, тем самым оставив за чертой исследования взаимосвязь с правом.

Также на самых ранних стадиях изучения проблемы правового регулирования общественных отношений в информационной сфере отрицалось существование самостоятельных информационных прав [6]. Эту точку зрения некоторые авторы поддерживают и сегодня считая, что юридическая природа информационного правоотношения определяется юридической природой тех отраслевых правоотношений, в рамках которых оно существует [7].

С целью исследования правового регулирования общественных отношений, связанных с информацией, В.А.Копылов предложил под информационными правоотношениями понимать урегулированные информационноправовой нормой информационные общественные отношения, стороны которого выступают как носители взаимных прав и обязанностей, установленных и гарантированных информационно-правовой нормой [8]. При этом В.А.Копылов в перечень информационных общественных отношений включает отношения, которые возникают, развиваются и прекращаются в информационной сфере при обороте информации.

Несколько конкретнее, но недостаточно полно С.Е.Чаннов определяет информационные правоотношения, как общественные отношения, возникающие в информационной сфере по поводу создания, преобразования, хранения, передачи, распространения и потребления информации [9].

Возникает довольно много вопросов, требующих или уточнения, или объяснения. Например, что такое ресурсы информации? Информация - это то, по поводу чего возникают общественные отношения или информация является объектом этих отношений? Таким образом, данное исследование использует дефиницию «информационные права», формируя заведомо субьектно направленную систему информационных правоотношений.

В таком подходе достаточно мало трактовок понятия «информационных прав» и они достаточно широки. Так, авторы сводят информационные права только к социальным отношениям по поводу создания, владения и пользования информацией, происходящих в информационной сфере, и урегулированные информационноправовыми нормами [10].

А.А.Федоров утверждает, что информационные права - это отношения, которые урегулированы нормами информационного права, возникающие в процессе оборота информации и устанавливают для субъектов взаимные права и обязанности [11].

Интересные результаты проведенных исследований в других отраслях права, связанных с изучением специфики информационных прав. Так, Д.Е.Иванов считает, что информационные права можно определить как урегулированные нормами права общественные отношения по делам об административных правонарушениях в связи с созданием, сбором, обработкой, накоплением, хранением, поиском, получением, распространением и потреблением информации в государстве и обществе, а также процессы создания и применения информационных систем, информационных технологий и средств их обеспечения, средств и механизмов информационной безопасности [12]. В этом определении автор не упоминает о субъективные юридические права и обязанности, но можно предположить, что упомянутые им нормы права уже содержат их. Кроме того, здесь сделана попытка ввести множество информационных правоотношений и отношения в информационной инфраструктуре, хотя далеко не в полном их объеме.

Ряд авторов для более строгого описания модели информационной сферы вводят понятие смешанных информационных прав субъектов: информационно-гражданские, информационно-административные, конституционно-информационные и тому подобное. Тем самым делается попытка правильно отразить тот факт, что в реальной действительности практически все виды общественных отношений сопровождаются информационными.

Наиболее системно этот подход сформули- 
рован Ю. В. Волков [13]. По нашему мнению, указанный выше подход целесообразно взять за основу при исследовании общественных отношений, возникающих в интегративной информационной публичной сфере. Она предлагает общественные отношения в информационной сфере рассматривать как системное образование, состоящее из двух подсистем: «смешанных» и «чистых» информационных общественных отношений. В свою очередь в первую подсистему входят:

a) информационно-управленческие, информационно-имущественные, информационно-банковские, информационно-трудовые и другие отношения;

б) управленческо-информационные, имущественно-информационные, банковско-информационные, трудо-информационные и другие отношения.

В первой группе информационные отношения являются основными, а все остальные (управленческие, имущественные, банковские, трудовые и т.д.) - обеспечивают другие, или являются сопутствующими, а во второй группе - наоборот, информационные отношения обеспечивают другие, или сопутствуют [14]. Предложенная модель общественных отношений, возникающих в информационной сфере, системная и наглядная, позволяет объяснить все особенности информационных процессов наряду с существованием других процессов в социуме в рамках рассмотрения субъективных прав доступа к публичной информации различного рода.

Далее автор предлагает отнести к информационной сфере только «чистые» информационные отношения и общественные отношения первой группы первой подсистемы: информационно-управленческие, информационнымиимущественные, информационно-банковские, информационно-трудовые и тому подобное.

Однако такой подход содержит очень серьезную методологическую проблему. Если допустить, что информационное право - это право, которое распространяется только на общественные отношения в информационной сфере, то это приводит к выводу о существовании еще какого-то права, нормы которого используются для регулирования информационных отношений во второй группе первой подсистемы общественных отношений: управленческо-информационных, имущественно-информационных, банковско-информационных, трудо-информационных и др.

Обобщение определений информационноправовых отношений сделано Л.П.Коваленко, которая определяет их как общественные отношения, регулируемые нормами права и те, которые возникают, развиваются и прекращают свое действие в информационном пространстве между субъектами права, которые наделены информационными правами и обязанностями [15]. Автор при этом опирается на заимствованное определение информационного пространства как информационных процессов и отношений.

Анализ содержания информационных процессов, научной литературы и многочисленных дефиниций, данных разными авторами, позволяет сформулировать характерные особенности информационных прав, показанные на рис. 1.

Выводы: В целом в информационном праве в результате использования наработанных подходов в общей правовой науке существует практически общее понимание природы и содержания правоотношений в информационной сфере. Но только в части общественных отношений, объектом которых является доступ к публичной информации в процессе ее оборота (создание, распространение, использование, хранение и уничтожение). Информационноинфраструктурные отношения, то есть общественные отношения, связанные с обеспечением оборота публичной информации, во многих исследователей выпадают из поля зрения. Однако понимание того, что целый пласт общественных отношений, имеющих место в информационной сфере, не охватывается классическими определениями информационных прав, обусловливает необходимость теоретических попыток восполнить этот пробел. Используя выявленные особенности, дадим определение термина «информационные права» - это информационные и информационно-инфраструктурные общественные отношения, регулируемые нормами информационного права и отражающие права, возникающие в процессе оборота информации, то есть в процессе ее создания, распространения (передачи), хранения, использования и уничтожения (утилизации), а также в процессе обеспечения оборота информации между субъектами, которые имеют субъективные права и юридические обязанности, реализуемые методами правового регулирования частного и публичного права. 
1. Информационные права - это права, которые возникают между субъектами в процессе оборота информации, то есть общественные отношения в процессе создания, распространения (передачи), хранения, использования и уничтожения (утилизации) информации.

2. Информационно-инфраструктурные права, которые возникают между субъектами в процессе обеспечения оборота информации, то есть общественные отношения, связанные с:

•- особенностями жизненного цикла существования (функционирования) субъектов

информационной инфраструктуры как юридических лиц;

- - предоставлением информационных услуг и выполнением информационных работ в процессе

создания, распространения (передачи), хранения, использования и уничтожения (утилизации) информации;

- производством и использованием информационных технологий и ресурсов, в том числе с использованием ограниченных ресурсов;

•- обеспечением информационной безопасности.

3. Информационные и информационно-инфраструктурные общественные отношения могут быть простыми автономными или частью сложных по составу общественных отношений.

4. Юридическая природа информационных и информационноинфраструктурных общественных отношений определяется природой информационного права.

5. Информационные и информационно-инфраструктурные общественные отношения регулируются нормами информационного законодательства.

6. Субъекты правоотношений в информационной сфере - это субъекты права, имеют субъективные права и юридические обязанности.

7 Субъективные права и юридические обязанности в информационной сфере реализуются методами правового регулирования частного и публичного права

Puc. 1. Характерные особенности информационных прав

\section{Библиографический список}

1. Revina S.N., Sidorova A. V., Zakharov A. L., Tselniker G.F., Kurushin S.A. Dissemination issues of legal information: the past and the present. Contributions to Economics. 2017. № б/н. С. 161-167.

2. Поляков А.В. Общая теория права: Феноменолого-коммуникативный подход. Курс лекций. 2-е изд., доп. / А. В. Поляков.-СПб.: изд-во «Юридический центр Пресс», 2003.- С. 726.

3. Кечекъян С. Ф. Правоотношения в социалистическом обществе [Электронный ресурс] / С. Ф. Кечекъян.- М., 1958. - 188 с. - Режим доступа: http://www.pravo.vuzlib.org/book_z622_page_28.html

4. Бекбаев Е. 3. Проблема начала в теоретическом познании правовой системы (попытка обоснования) [Электронный ресурс] / Е.З.Бекбаев.- Астана, 2008. - 296 с.- Режим доступа: http://www.allpravo.ru/library/ doc108p0/instrum7129/print7135.html

5. Абдулаев М.И. Теория государства и права. 3-е изд., дополн. / М.И.Абдулаев.- М.: Финансовый контроль, 2014. -410 c.

6. Брагинский М. И. Правовое регулирование информационных отношений в условиях АСУ / М. И. Брагинский // Советское государство и право.-1976.- № 1.- С. 38-46. 
7. Янина Е. В. Гражданско-правовое регулирование информационной безопасности: дис. ... канд. юрид. наук: спец. 12.00.14 / Е. В. Янина.- М., 2004.-166 с.

8. Копылов В. А. Информационное право / В.А. Копылов.- М.: Юристъ, 2002. - 512 с.

9. Чаннов С.E. Информационное право как комплексная отрасль российского права [Электронный ресурс].Режим доступа: http://www.tarasei.narod.ru/read/st2003.8.htm

10. Боер В. М. Информационное право: учеб. пособие. Ч. 1 / В. М.Боер, О.Г.Павельева.;.- СПб.: ГУАП, 2006.$116 \mathrm{c}$.

11. Федоров А. А. Информационное право как отрасль системы права // Актуальные вопросы информационной деятельности в системе государственного управления.- Донской государственный технический университет, факультет «Юридический».-2019.- С. 515-518.

12. Иванов Д. Е. Информационные правоотношения в производстве по делам об административных правонарушениях: автореф. дис. на соискание учен. степени канд. юрид. наук: спец. 12.00.14 адм. право, финансовое право, информ. право. / Д.Е. Иванов.- М.: Моск. ун-т МВД России, 2005. - 27 с.

13. Волков Ю.В. Базовые субъекты информационного права // Законодательство. - 2019. - № 9.- С. 47-54.

14. Чубукова С.Г. Системы субъектов информационного права: направления цифровой трансформации // Вестник Московского университета. Серия 26: Государственный аудит. - 2019._№ 3.- С. 17-27.

15. Коваленко Л.П. Понятие, основные черты и особенности правовых отношений в информационном праве [Электронный ресурс] / Л.П. Коваленко - Режим доступа: http://jurnal.org/articles/2013/uri57.html

16. «Конституция Российской Федерации» (принята всенародным голосованием 12.12.1993 с изменениями, одобренными в ходе общероссийского голосования 01.07.2020)

17. Закон РФ от 27.12.1991 N 2124-1 (ред. от 01.03.2020) «О средствах массовой информации»

18. Распоряжение Правительства РФ от 01.11.2013 N 2036-р (ред. от 18.10.2018) <Об утверждении Стратегии развития отрасли информационных технологий в Российской Федерации на 2014-2020 годы и на перспективу до 2025 года> 